\title{
手指先の良導点で検出される 極微弱発光情報分析について［II ]
}

東北工業大学 情報処理技術研究所 神 正照、稲場文男

はじめに

これまでにヒト手指先から発生する極微弱 発光（生物フォトン）を計測し、生体光情報 的観点から検討を続けてきた。今回は手の $\mathrm{H}_{6}$ 大腸経の $\mathrm{H}_{6} 4$ 合谷に刺入し、同良導絡上にあ る $\mathrm{H}_{6} 1$ 商陽からの極微弱発光があるかを調 ベたので報告する。

\section{方法}

測定には、これまでに用いた高感度極微弱 発光計測装置を同様に使用し、完全に外部か らの光が入らないように暗室の中で行った。 測定部位は、右手人差し指の指腹と $\mathrm{H}_{6} 1$ 商陽 の所である。最初になにも刺激を加えない状 態でこの両者を計測し、次に左手の $\mathrm{H}_{6} 4$ 合谷 に銊を刺入し同様の計測を行った。測定時間 は、それぞれ100秒間づつ計測した。 $\mathrm{H}_{6} 4$ 合 谷に鐵を刺入し単刺法を用い $\mathrm{H}_{6} 1$ 商陽で計 測を行った。

\section{䊅果及び考察}

測定対象には、 5 人の医療従事者の男性 $(40$ 代）で行った。測定は、 $\mathrm{H}_{6} 4$ 合谷に鍼を刺入 した場合と、しない場合の比較を行った。そ の結果、鍼を刺入した方が発光強度が高くな る傾向が見いだされた。 $\mathrm{H}_{6} 4$ 合谷と観測した $\mathrm{H}_{6} 1$ 商陽は良導絡的連絡があるため、刺入と 同時に刺激の伝搬が良導絡を通して伝わるも のと思われる。このことが今回、良導絡上に
ある経穴はお互いに関連していることが、生 物フォトンを計測することにより物理的に観 測された。また、今回の測定で刺針前後の極 微弱発光量に変化のあることが示唆された。

図 1 は測定結果の例で、左手合谷穴に銊を 刺入して、右手の商陽穴で生物フォトン発光 を計測した結果を示すものである。

この中で特に顕著に表れたのは 5 人の被験 者の中少し寝不足の者であった。

\section{おわりに}

これまでに行ったこのような手指先の経穴 からの生物フォトン発光計測の結果、統計的 に健康な人の場合、個々の発光特性があるも のと思われる。しかし、体調が思わしくない 場合、二日酔い、睡眠不足等の場合は発光特 性が時間的に変化していくことが確かめられ た。これは治療（鍼炎）を行う場合、治療前 後を比較する事により生体光情報の変化で治 療評価を行う事ができるものと考えられる。

\section{文献}

1) 神 正照、稲場文男、宇佐 史、小林正樹、 B.DEVARAJ、武田元博: 日本良導絡医学会 学術論文集、94, 1994.

2 ）神 正照、稲場文男、宇佐 “史、小林正樹、 B.DEVARAJ、武田元博: 東北工業大学情報 処理研究所紀要 ESO, 77, 1995. 


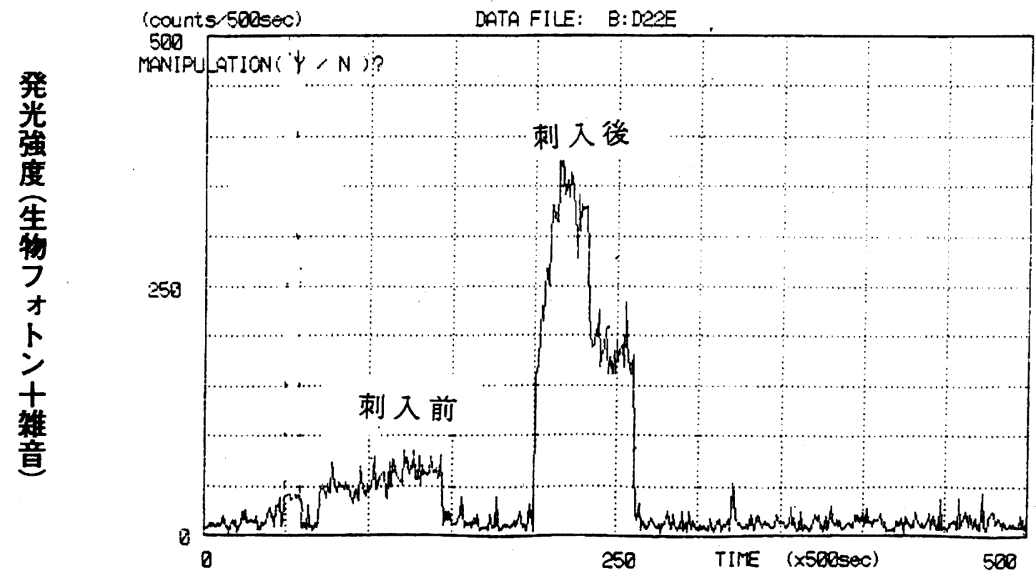

図 1 手の $H_{6}$ 大䳟経の $H_{6} 1$ 商陽で計測左手 $H_{6} 4$ 合谷に刺入した場合 